\title{
SECAGEM POR ATOMIZAÇÃO DE EXTRATO DA TORTA DE AMÊNDOAS DE BABAÇU USANDO GOMA ARÁBICA COMO AGENTE ENCAPSULANTE
}

\section{Pãmella Fronza Câmara ${ }^{1}$; Abraham Damian Giraldo Zuniga ${ }^{1}$; Robson dos Santos Barbosa²; Jéssica da Silva Ferreira ${ }^{3}$; Fabiana Oliveira Pereira ${ }^{1}$; Amanda Galvão Maciel ${ }^{3}$; Thiago Silva Novais $^{1}$; Paloma Cecilia Queiroz Ferreira ${ }^{4}$}

1 Programa de Mestrado em Ciência e Tecnologia de Alimentos - Universidade Federal do Tocantins (UFT), Brasil.

2 Programa de Mestrado em Agroenergia - Universidade Federal do Tocantins (UFT), Brasil.

3 Curso de Engenharia de Alimentos - Universidade Federal do Tocantins (UFT), Brasil.

4 Curso de Nutrição - Universidade Federal do Mato Grosso (UFMT),Brasil. (palomacecilia_@hotmail.com)

Diante da diversidade de frutos encontrados no Brasil, merece destaque o babaçu, cientificamente chamado de Orbignya phalerat Martiana, encontrada principalmente nas regiões Norte e Nordeste do Brasil, que apresenta grande valor socioeconômico, podendo dar origem a diversos produtos e subprodutos. O óleo obtido da amêndoa é o único produto produzido em escala comercial, sua extração dá origem a torta residual, destinada em poucos casos à produção de ração animal, todavia suas características permitem que a mesma seja incorporada no processamento de alimentos. Na literatura poucos são os estudos voltados para obtenção de produtos alimentícios utilizando essa matéria-prima que apresenta grande potencial. Sendo assim o presente trabalho teve a finalidade de verificar a influência da temperatura e concentração de goma arábica no processo de secagem de extrato da torta de amêndoas de babaçu. Foram utilizados amêndoas de coco babaçu provenientes do município de São Miguel- TO, para aquisição da torta residual e do extrato hidrossolúvel. A torta obtida foi homogeneizada em liquidificador industrial na proporção de $2: 1$ sendo, 2 partes de água quente $\left(85^{\circ} \mathrm{C}\right)$ e 1 parte de torta por um período de 15 minutos até consistência homogênea em seguida o material foi filtrado para separação da parte sólida e líquida. Para condução da secagem foi utilizado um spray dryer, onde adotou-se um delineamento composto central rotacional (DCCR com 11 ensaios). O planejamento experimental apontou efeito significativo ao nível de $95 \%$ de confiança para a temperatura e concentração no termo linear, além disso os efeitos se mostraram negativos. A secagem com goma arábica apresentou um rendimento de $40,32 \%$ em temperatura de $70,9^{\circ} \mathrm{C}$ e concentração de $14 \%$, assim baixas temperaturas e concentrações de agente encapsulante caracterizam essas condições como aceitáveis para o processamento, uma vez que a goma arábica possui um custo relativamente alto no mercado. Dessa forma, novos produtos alimentícios podem ser elaborados a partir do extrato hidrossolúvel obtido.

Palavras-chave: Babaçu, atomização, goma arábica. 